\title{
Mychonastes frigidus sp. nov. (Sphaeropleales/Chlorophyceae), a new species described from a mountain stream in the Subpolar Urals (Russia)
}

\author{
Elena Patova ${ }^{1 *}$, Irina Novakovskaya ${ }^{1}$, Nikita Martynenko ${ }^{2}$, Evgeniy Gusev $^{2} \&$ \\ Maxim KuLIKOvsKIY ${ }^{2}$
}

\author{
${ }^{1}$ Institute of Biology FRC Komi SC UB RAS, Kommunisticheskaya Street 28, Syktyvkar, 167982, Russia, \\ *Corresponding authore-mail: patova@ib.komisc.ru \\ ${ }^{2}$ K.A. Timiryazev Institute of Plant Physiology RAS, Botanicheskaya Street 35, Moscow, 127276 Russia
}

\begin{abstract}
This paper describes a new species from the Class Chlorophyceae, Mychonastes frigidus sp. nov., isolated from a cold-water mountain stream in the north of Russia (Subpolar Ural). The taxon is described using morphological and molecular methods. Mychonastes frigidus sp. nov. belongs to the group of species of the genus Mychonastes with spherical single cells. Comparison of ITS2 rDNA sequences and its secondary structures combined with the compensatory base changes approach confirms the separation between Mychonastes frigidus sp. nov and other species of the genus. Mychonastes frigidus sp. nov. represents a cryptic species that can only be reliably identified using molecular data.
\end{abstract}

Key words: Mychonastes, new species, SSU rDNA, ITS2 rDNA secondary structure, CBC approach, Subpolar Urals

\section{INTRODUCTION}

The genus Mychonastes P.D. Simpson \& Van Valkenburg 1978 comprises autosporic small-celled organisms that live alone, in small groups or organized in colonies, surrounded by hyaline, mucilaginous envelopes without distinctive structures. Species of the genus are common in phytoplankton in stagnant and running fresh and brackish waters. It is difficult to differentiate most taxa of the genus Mychonastes from other single small-celled, spherical or ellipsoidal chlorophytes such as Choricystis (Skuja) Fott, Meyerella Fawley et K. Fawley and Nannochloris Naumann (KrienitZ et al. 1996, 1999; FAwLeY et al. 2005) under light microscopy.

Like many other green algae, morphological convergence and high levels of morphological plasticity complicate the application of traditional classification methods in this genus. Molecular data have demonstrated that the Mychonastes clade represents a monophyletic lineage within the Chlorophyceae, which is clearly differentiated from other evolutionary lineages containing small-celled coccoid green algae (KRIENITZ et al. 2011). Notably, KriENITZ et al. (2011) stated that only molecular data can provide conclusive evidence for the characterization and separation of species of the genus Mychonastes.

Species of this genus have previously been repeatedly noted in terrestrial habitats in the northern regions of the Urals (Patova \& NovakovskaYa 2018). The Subpolar Urals comprises the northernmost part of the Ural Mountains in Russia. It is the highest part of the Ural mountain system, which is a complex folded structure of the Upper Paleozoic age. Unlike other parts of the Urals, it is characterized by a peculiar landscape, orography and climate (TRESHNIKOV 1985). The border position between the European continent and Siberia (or Europe and Asia) and the complex natural processes of the last millennia associated with glaciation have led to the region's richest diversity of flora and fauna, which combine tundra and forest species and elements of western and eastern species. The flora of vascular plants in the region comprises more than 600 species, including a number of endemic taxa (Degteva 2016). The algal flora of the Subpolar Urals is represented by 125 species of cyanoprokaryotes and 704 eukaryotic algae taxa, including 57 chlorophytes species (Patova 2010). Soil algal flora include 75 taxa of cyanoprokaryotes and 133 taxa of eukaryotic algae, including 68 species of chlorophytes (Patova \& NovakovskaYa 2018). Data on the diversity of algae in this territory is actively increasing through the study of previously inaccessible areas, as well as through the application of new molecular methods to the study of algae.

Here, we use molecular data to describe a new 
species of the genus Mychonastes from a cold-water stream in the Subpolar Urals.

\section{Material ANd Methods}

Study area. Sample was collected from an unnamed mountain stream in the Subpolar Urals on August 8, 2015 at GPS coordinates $65^{\circ} 12^{\prime} 48^{\prime \prime} \mathrm{N}, 60^{\circ} 16^{\prime} 04^{\prime \prime} \mathrm{E}, 676 \mathrm{~m}$ above sea level (Fig. 1). The research area is located in the northeast of the European part of Russia, in the Intinsky administrative region of the Komi Republic, and is included in the borders of the "Yugyd va" national park (Treshnikov 1985). The climate is severe and sharply continental, which is due to the geographical location of the region and the considerable height of the mountain ridges (KoLESNIK 1964). The Subpolar Urals have the highest precipitation of the Urals; in the western slopes where this stream is located the annual precipitation reaches 1500 $\mathrm{mm}$. The average annual air temperature is $-4.4^{\circ} \mathrm{C}$. The area has a well-developed river network; all rivers originate on the western slope of the Ural ridge and often start from small but deep lakes. Rivers accounts for $50-60 \%$ of the snow supply, up to $30 \%$ of the rain supply, and $15-20 \%$ of the underground water supply (KOLESNIK 1964).

Samples and collection. Samples were collected from a rocky stream bottom consisting of white quartz. A scraping of yellow-green plaque was collected from the stones. The water temperature at the time of collection was $12^{\circ} \mathrm{C}, \mathrm{pH}$ $=6.0$, and the specific conductance was $21 \mu \mathrm{S} \cdot \mathrm{cm}^{-1}$. Other environmental parameters of the water are presented in Table. Water mineralization and temperature measurements were performed using the HI98129 Combo (Hanna Instruments, Inc., Woonsocket, RI, USA). Hydrochemical analysis was conducted at the eco-analytical laboratory of the Institute of Biology FRC Komi SC UB RAS. The strain described here was isolated by E. Patova and I. Novakovskaya, and cultures were transferred to the Collection of microalgae strains in the Institute of Biology FRC Komi SC UB RAS under the number SYKOA Ch-111-18.

Culturing. The sample was placed immediately in the field in a sterile Waris-H medium (McFADDEN \& MELKONIAN 1986). Monoclonal strain was established by examination of micropipetted single cells under an inverted microscope. Non-axenic unialgal cultures were maintained in Waris-H liquid medium at $10^{\circ} \mathrm{C}$ in a growth chamber with a $12: 12 \mathrm{~h}$ light:dark photoperiod. Morphological features were investigated after cultivation on 3N BBM, WC, BG-11 liquid and agar mediums (ANDREYEVA 1998; ANDERSEN 2005).

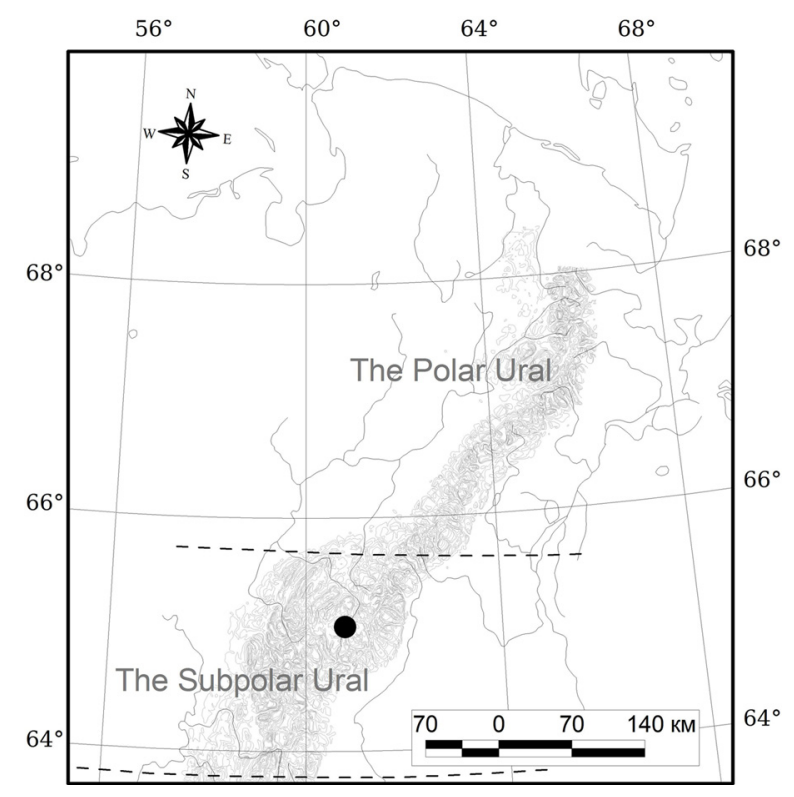

Fig 1. Map of the study area.

Light microscopy. Light microscopy observations and photography were carried out using a Zeiss Scope A1 microscope (Carl Zeiss AG, Oberkochem, Germany), equipped with an oil immersion objective (Plan-Apochromat 100×/1.40 Oil DIC M27) and Nikon Eclipse80i (Nikon, Japan) equipped with an oil immersion objective (Plan-Fluor 100×/1.30 Oil DIC D-ND 6 ) at $1000-$ fold magnification. Cells were stained with $0.1 \%$ methylene blue solution and $1.0 \%$ ink solution for the determination of the mucilage structure. Cultures in exponent and stationary growth phases.

Light micrographs were taken with an AxioCam ERc 5s Rev. 2 and Nikon Digital Sight Ds $-2 \mathrm{Mv}$ cameras. Nikon Eclipse80i (Nikon, Japan) with optics of Nomarskiy (DIC).

Extraction of DNA and amplification. The total DNA of the monoclonal culture was extracted using InstaGeneTM Matrix according to the manufacturer's protocol. Fragments of SSU rRNA (1718 bp) and ITS2 rRNA (382 bp) were amplified using primers EukA and EukB from MEDLIN et al. (1988) for SSU rRNA fragments and ITS1-ITS4 from WhITE et al. (1990) for ITS2 rRNA fragments. Amplification of all studied fragments was carried out using the premade mix ScreenMix (Evrogen, Russia) for the polymerase chain reaction (PCR). The conditions of amplification for both SSU rRNA and ITS2 rRNA fragments were: an initial denaturation of $5 \mathrm{~min}$ at $95^{\circ} \mathrm{C}$, followed by 35 cycles at $94{ }^{\circ} \mathrm{C}$ for denaturation $(30 \mathrm{~s}), 52^{\circ} \mathrm{C}$ for annealing $(30 \mathrm{~s})$ and $72^{\circ} \mathrm{C}$ for extension $(50-80 \mathrm{~s})$, and a final

Table 1. Environmental parameters of the studied stream.

\begin{tabular}{|c|c|c|c|c|c|c|c|c|c|c|c|}
\hline \multicolumn{7}{|c|}{$\begin{array}{l}\text { Major Ions } \\
\quad\left(\mathrm{mg.l}^{-1}\right)\end{array}$} & \multicolumn{5}{|c|}{$\begin{array}{l}\text { Major biogenic elements } \\
\text { (mg. }{ }^{-1} \text { ) }\end{array}$} \\
\hline $\mathrm{Cl}^{-}$ & $\mathrm{SO}_{4}^{2-}$ & $\mathrm{HCO}_{3}^{-}$ & $\mathrm{Ca}^{2+}$ & $\mathrm{Mg}^{2+}$ & $\mathrm{Na}^{+}$ & $\mathrm{K}^{+}$ & $\mathrm{P}_{\text {mineral. }}$ & $\mathrm{P}_{\text {total. }}$ & $\mathrm{N}_{\text {total. }}$ & $\mathrm{Si}$ & $\mathrm{Fe}_{\text {total }}$ \\
\hline 0.27 & $\begin{array}{c}\text { not } \\
\text { detected }\end{array}$ & 5.1 & 1.62 & 0.153 & 0.83 & 0.058 & 0.004 & 0.009 & 0.56 & 5.0 & $\begin{array}{c}\text { not } \\
\text { detected }\end{array}$ \\
\hline
\end{tabular}


extension of $10 \mathrm{~min}$ at $72{ }^{\circ} \mathrm{C}$. The resulting amplicons were visualized by horizontal agarose gel electrophoresis (1.5\%), colored with SYBR Safe (Life Technologies, Carlsbad, CA, USA). Purification of DNA fragments was performed with the ExoSAP-IT kit (Affymetrix, Santa Clara, CA, USA) according to the manufacturer's protocol. SSU rRNA and ITS2 rRNA fragments were decoded from two sides using forward and reverse PCR primers and the Big Dye system (Applied Biosystems, Foster City, CA, USA), followed by electrophoresis using a Genetic Analyzer 3500 sequencer (Applied Biosystems, Foster City, CA, USA).

Phylogenetic analysis of SSU rDNA data. Sequences were edited manually and assembled using BioEdit v7.1.3, and MegaX (Kumar et al. 2018). Newly determined sequences and GenBank sequences of 42 other chlorophytes from different morphological groups were included in the alignment. Also, two species (Ulothrix zonata (F.Weber et D.Mohr) Kütz. and Gloeotilopsis planctonica M.O.P.Iyengar et Philipose) were chosen as outgroup taxa. Sequences were aligned using global SILVA alignment for rRNA genes in the SINA v1.2.11 (Pruesse et al. 2012). jModelTest ver. 2.1.1 indicated that the GTR model of nucleotide substitution, with Gamma (G) distributed rates across sites and a proportion of invariable sites (I), was the most appropriate evolutionary model for the SSU rDNA alignment (POSADA 2006). Maximum likelihood phylogeny (ML) was constructed using MegaX (Kumar et al. 2018) with the Subtree-Pruning-Regrafting tree rearrangements algorithm (SPR). The bootstrap analysis with 1,000 replicas was used. Bayesian Interference (BI) analysis was conducted with MrBayes-3.2.5 (RoNQuist \& HuELSENBECK 2003). Three "hot" and one "cold" Markov chains were run for $1 \times 10^{6}$ cycles in two repetitions with the selection of each 200th generated tree. Phylogenetic tree and posterior branching probabilities were obtained after discarding the first $25 \%$ to produce estimate parameter models of nucleotide substitutions and likelihood. Viewing and editing of trees were carried out in the programs FigTree (ver 1.4.2) and Adobe Photoshop CC (19.0).

Internal transcribed spacer 2 annotation, phylogeny, and secondary structure modeling. For the annotation ITS2 sequence, was used tool ITS2-Annotation (ANKENBRAND et al. 2015). This tool uses HMMer (EDDY 1998) to annotate ITS2 sequences with Hidden Markov Models (HMMs) (KeLLER et al. 2009). It returns by definition of the ITS2 the sequence between the conserved $5.8 \mathrm{~S}$ and $28 \mathrm{~S}$ (or equivalent) rRNA funding region. The secondary structure of the ITS2 rDNA region was modeled using the Mfold version 2.5 program (ZUKER 2003). The construction of the model took into account the presence of the pyrimidine-pyrimidine unpaired section in the second helix at seventh position (CAISOvá et al. 2013), as well as the length and nucleotide composition of the spacers in the core of the model defining the helix boundaries (SChultz et al. 2005). Detail features of the ITS2 secondary structures of studying species, for example, presence of helices $\mathrm{Ib}$ and IIIb, were also checked using secondary structures of others Mychonastes species (KRIENITZ et al. 2011). The resulting secondary structure was visualized in the program PseudoViewer3 (BYUn \& HAN 2006). The ITS2 sequences were aligned according to the secondary structure by ClustalW algorithm (Thompson et al. 1994) in tool 4SALE (SEIBEL et al. 2006). For delimitations species secondary structures of Mychonastes strains were checked for compensatory base changes (CBCs) according to COLEMAN $(2000,2009)$; MüLLER et al. (2007) in comparison with species described by KRIENITZ et al. (2011). For the phylogenetic analysis the sequence part from the sequence-structure alignment (as obtained by 4SALE) was further processed, using the same programs and methods as described above for the $18 \mathrm{~S}$ data, except for the model of nucleotide substitution - Kimura-2-parameter + I.

\section{ReSULTS}

Cells of the strain SYKOA Ch-111-18 are small, spherical, commonly solitary, and sometimes found in small groups after sporulation (Figs 2-5). Staining with $0.1 \%$ methylene blue solution and $1.0 \%$ ink solution did not reveal any stalks between cells. Analysis of the SSU rDNA gene sequences revealed that the strain SYKOA Ch-111-18 belongs in the Mychonastes clade on the phylogenetic tree of Chlorophyceae (Fig. 6). Thus, morphologically, the strain SYKOA Ch-111-18 belongs in a group with species $M$. homosphaera, M. pusillus, $M$. rotundus and $M$. huancayensis, which possess solitary spherical cells (see Supplementary table). Species in this group can be distinguished only by molecular criteria like ITS2 sequences and a presence of CBC in the conserved regions of ITS2 due to their small size, lack of sexual reproduction and high interspecies similarity (KRIENITZ et al. 2011). Analysis of the ITS2 rDNA sequences of the strain SYKOA Ch-111-18 allowed the recognition of the new lineage on the ITS2 rDNA tree referable to a new species (Fig. 7).

Mychonastes frigidus sp. nov. Patova, Novakovskaya, Martynenko, Gusev, Kulikovskiy (Figs 2-5)

Description: cells single or rarely in small groups (colonies), adult cells spherical, usually $2-5 \mu \mathrm{m}$, very rarely up to $10 \mu \mathrm{m}$ in old cultures, without mucilaginous envelope. Colonies usually four-celled, 9-15 $\mu \mathrm{m}$ in diameter, cells connected via mucilaginous mother cell wall remnants. The cell wall is thin, in the light microscope appears smooth. Chloroplast single, parietal, cup-shaped, without pyrenoid. Cytoplasm with oil droplets. Propagation by two or four (eight) autospores. Species differs from other species of the genus by the order of the nucleotides in ITS rDNA gene sequences.

Holotype: a large drop of unfixed dried cells of the strain SYKOA Ch-111-18 on watercolor paper (hic designatus), deposited at SYKO Herbarium, Komi Scientific Centre, Russian Academy of Sciences, Syktyvkar, Russia under the designation SYKO №1001-A. Representative strain and DNA sample deposited at the SYKOA Collection of microalgae strains in the Institute of Biology FRC Komi SC UB RAS, Russian Academy of Sciences under the designation SYKOA Ch-111-18. The strain is also conserved as a formaldehyde-fixed sample.

Authentic strain: SYKOA Ch-111-18.

Representative DNA sequences: GenBank accession numbers MT192073 (nuclear ITS2 rDNA), and MT187587 
(nuclear SSU rDNA).

Etymology: the specific epithet (frigidus) reflects the occurrence of this species in cold waters.

Type locality: an unnamed mountain stream in the Subpolar Urals of Russia. Latitude/Longitude: $65^{\circ} 12^{\prime} 48^{\prime \prime} \mathrm{N}$, $60^{\circ} 16^{\prime} 04^{\prime \prime}$ E, elevation $676 \mathrm{~m}$ above sea level. Collected August 8, 2015 by E. Patova.

Distribution: To date, Mychonastes frigidus has only been observed in the type locality. At the time of collection, the $\mathrm{pH}$ was 6.0 , temperature $12{ }^{\circ} \mathrm{C}$ and specific conductance $21 \mu \mathrm{S} . \mathrm{cm}^{-1}$.

\section{Discussion}

The genus Mychonastes includes solitary or colonial (4-64 cells or more) algae with or without mucous membrane. Mucous colonies are spherical, ovoid or irregular in shape. In the colonies, the cells are connected by gelatin filaments, which are formed by the remnants of the cell wall of the mother cell after sporulation. The cells have a spherical, slightly ovoid or ellipsoidal shape, 1.5-10 $\mu \mathrm{m}$ in diameter. The cell wall is sculptural and consists of two layers: an outer layer with a trilaminar substructure and an amorphous inner layer. A cell contains from one to four chloroplasts, disk-shaped, mantle-shaped, or, most often, cup-shaped, without a pyrenoid; each cell has one nucleus. With aging, secondary carotenoids can form, making cultures yellow, orange, or brown. Reproduction occurs via autospores (usually 2-4-8 (16)), which are released by rupture of the maternal membrane. The remains of the maternal membrane are preserved in the medium (ANDREEVA 1998; KRIENITZ et al. 2011).

The genus is currently represented by 20 species in Algaebase (GUIRY \& GUIRY 2020); their characteristics and habitat preferences are described in Supplementary table. Species of this genus were previously found in Scotland, Germany, Slovakia, Russia, Ukraine, Brazil, Peru, Kenya, Angola, India, USA (SimPson \& VALKENBURG 1978; HindÁK 1978; KOMÁREK \& FOTT 1983; HINDÁK 1984; HindáK 1988a, b; ANDREYEVA 1998; HaNAGATA et al. 1999; TSARENKO et al. 2011; KRIENITZ et al. 2011; RAmos et al. 2015, etc).

Mychonastes frigidus clustered with M. homosphaera, M. pusillus, M. rotundus and M. ovahimbae on unrooted ITS2 tree and formed a separate branch inside this cluster (Fig. 7). This result is in general accordance with the results of morphological analysis, which indicated that $M$. frigidus belongs in a group of species with solitary spherical cells. Comparison of the ITS2 secondary structures of $M$. frigidus with other species with known ITS2 rDNA sequences revealed a number of CBCs with all studied taxa, including highly conserved
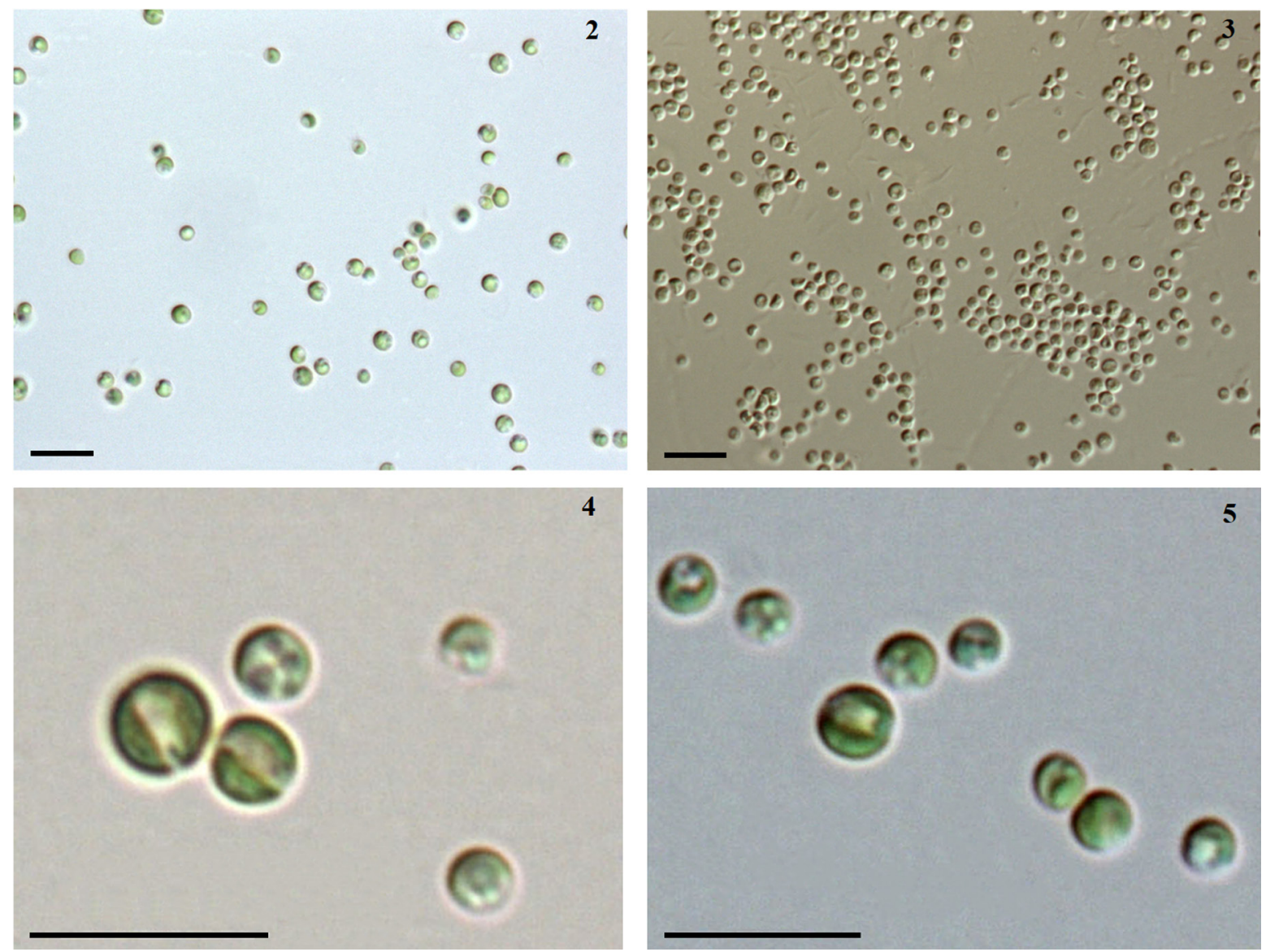

Figs 2-5. Microphotographs of Mychonastes frigidus sp. nov. Scale bars $10 \mu \mathrm{m}$. 


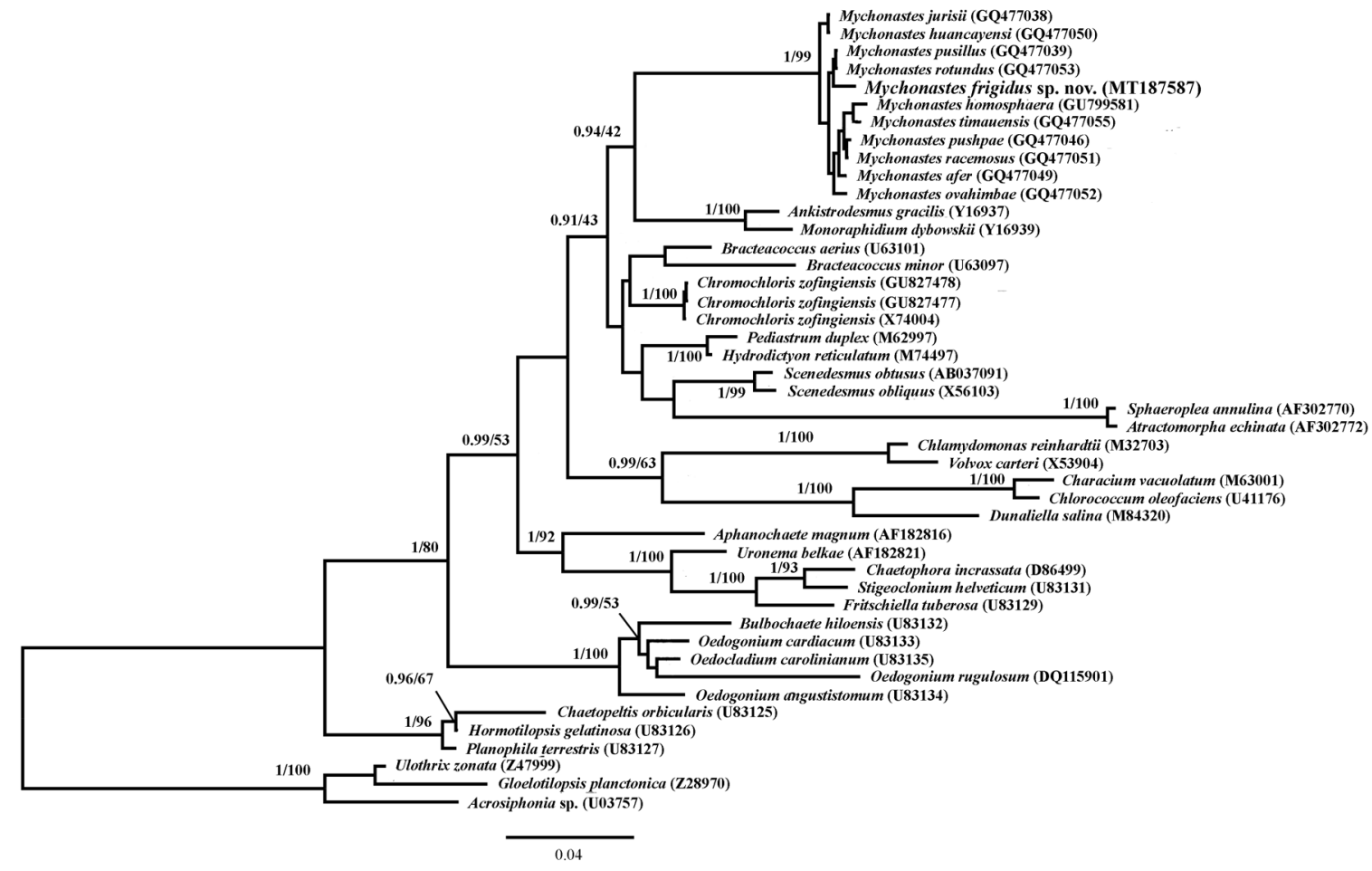

Fig. 6. Bayesian tree of the partial small subunit rDNA (SSU rDNA). The Bayesian posterior probability and maximum likelihood bootstrap value are shown left and right of the fraction line respectively. Scale bar represents: substitution per site.

areas of Helix III (Fig. 8). All Mychonastes taxa are characterized by variability in the length and structure of the second and third helices. M. frigidus, M. pusillus and $M$. rotundus have similar ITS2 lengths (379-382 nt). There were 2 and 3 CBCs in the Helix III comparing $M$. frigidus with $M$. pusillus and $M$. rotundus, respectively (Fig. 8). M. homosphaera and M. ovahimbae are differ in the length of ITS2 (337 and $361 \mathrm{nt}$, respectively) and have 4 and 2 CBCs in the Helix III comparing $M$. frigidus, respectively (Fig. 8). Among the discussed taxa, M. pusillus is known from Kenya, M. ovahimbae from Angola, $M$. rotundus from Kenya and Germany and $M$. homosphaera from Sweden, the Czech Republic and Germany (KRIENITZ et al. 2011).

The $\mathrm{CBC}$ concept was previously used for species delimitation in the Mychonastes clade (KRIENITZ et al. 2011). COLEMAN (2000) and MüLLER et al. (2007) have proposed that CBCs in ITS2 correlate with speciation, and thus can be used to distinguish species. The CBC species concept states that two organisms/strains whose ITS2 sequences differ by even a single $\mathrm{CBC}$ in the conserved regions of Helix II and Helix III represent two different biological species (COLEMAN 2000). According to MülLER et al. (2007) and Wolf et al. (2013), the presence of any CBC in the whole ITS2 molecule is sufficient for distinguishing species.

Species of the genus Mychonastes are one of the most abundant groups of algae of picoplankton and nanoplankton of fresh and brackish waters (KRIENITZ et al. 2011). However, Mychonastes frigidus was isolated from epilithon on the stream bottom and differs in ecology from other described taxa. This new species has some special preferences: it inhabits cold waters with low content of biogenic elements and shows good growth at low temperatures. It has so far been found only in the type habitat in Northern Russia. The species may therefore represent a true cryptic species, which can only be distinguished by molecular characters.

\section{ACKNOWLEDGEMENTS}

The authors are grateful to T. Darienko for help in preparing the manuscript. This research was carried out as parts of the state assignment themes AAAA-A19-119041190086-6 (IPP RAS) and AAAAA19-119011790022-1 (IB FRC Komi SC UB RAS).

\section{REFERENCES}

ANDERSEN, R.A. (2005): Algal Culturing Techniques. - 589 pp., Elsevier/Academic, Burlington/San \& Diego/London. DOI: 10.1016/B978-012088426-1/50007-X.

ANDreyeva, V.M. (1998): Soil and aerophilic green algae (Chlorophyta: Tetrasporales, Chlorococcales, Chlorosarcinales). - 352 pp., Nauka, St. Petersburg.

Ankenbrand, M.J.; Keller, A.; Wolf, M.; Schultz, J. \& FÖRSTER, F. (2015): ITS2 database V: Twice as much. Molecular Biology and Evolution 32: 3030 -3032. DOI: $10.1093 / \mathrm{molbev} / \mathrm{msv} 174$.

Byun, Y. \& Han, K. (2006): PseudoViewer: web application and webservice for visualizing RNA pseudoknots and secondary structures. - Nucleic Acids Research 34: 416-422. DOI: 10.1093/nar/gk1210.

Caisová, L.; Marin, B. \& Melkonian, M. (2013): A consensus secondary structure of ITS2 in the Chlorophyta 


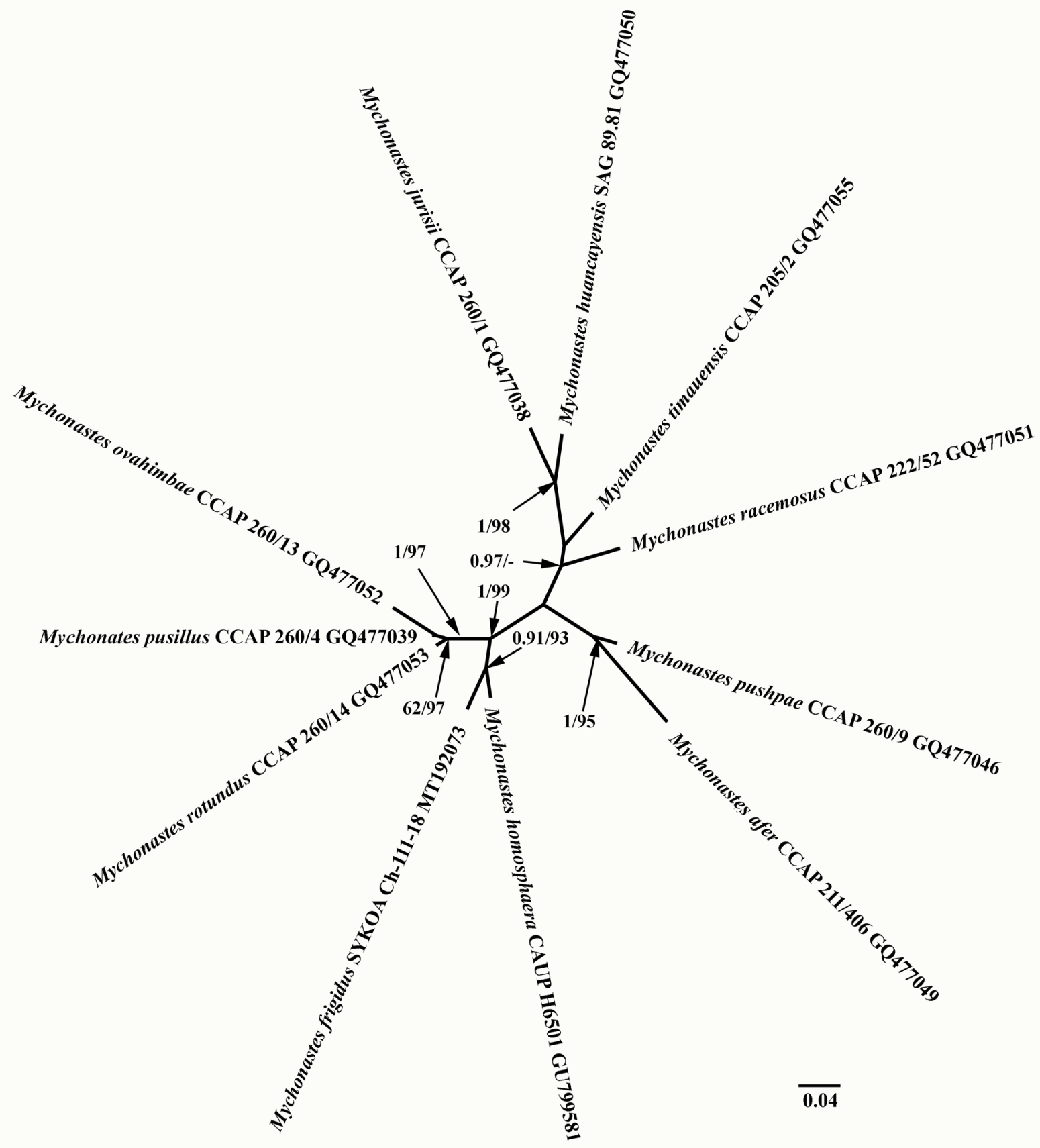

Fig 7. Unrooted Bayesian tree of the ITS2 rDNA of species from the genus Mychonastes. The Bayesian posterior probability and maximum likelihood bootstrap value are shown left and right of the fraction line respectively. Scale bar represents: substitution per site.

identified by phylogenetic reconstruction. - Protist 164: 482-496. DOI: 10.1016/j.protis.2013.04.005.

Coleman, A.W. (2000): The significance of a coincidence between evolutionary landmarks found in mating affinity and a DNA sequence. - Protist 151: 1-9. DOI: $10.1078 / 1434-4610-00002$.

Coleman, A.W. (2009): Is there a molecular key to the level of "biological species" in eukaryotes? A DNA guide. - Molecular phylogenetics and evolution 50: 197-203. DOI: 10.1016/j.ympev.2008.10.008.

DEGTEVA, S.V. (2016): Flora, licheno and mycobiota especially protected landscapes of the Kosyu and Bolshaja Synya river basins (Subpolar Urals, national park "Yugyd va"). - 483 pp., KMK scientific partnership, Moscow. EDDy, S.R. (1998): Profile hidden Markov models. Bioinformatics (Oxford, England) 14: 755-763. DOI: 10.1093/bioinformatics/14.9.755.

Fawley, M.W.; Fawley, K.P. \& Owen, H.A. (2005): Diversity and ecology of small coccoid green algae from Lake Itasca, Minnesota, USA, including Meyerella planktonica, gen. et sp. nov. - Phycologia 44: 35-48. DOI: 0.2216/0031-8884(2005)44[35:DAEOSC]2.0.CO;2.

GuirY, M.D. \& GuiRY, G.M. (2020): AlgaeBase. World-wide electronic publication, National University of Ireland, Galway. http://www.algaebase.org; searched on 18 May 2020. 
1 - M. homosphaera CAUP H6501

2 - M. huancayensis SAG 89.81

3 - M. ovahimbae CCAP 260/13

4 - M. pusillus CCAP 260/4

5 - M. rotundus CCAP 260/14

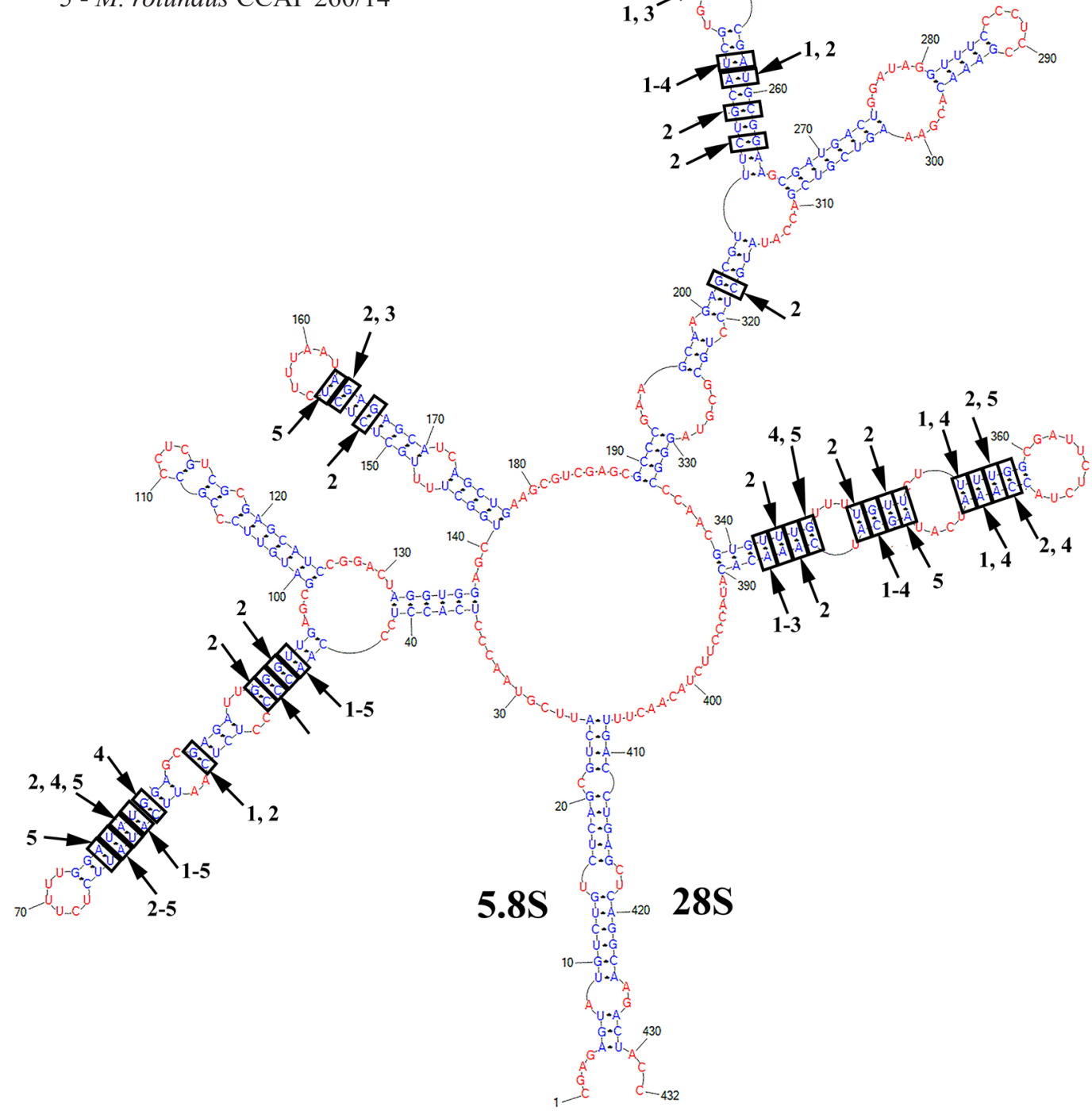

Fig 8. Predicted secondary structure of the nuclear internal transcribed spacer 2 of the strain SYKOA Ch-111-18 (Mychonastes frigidus sp. nov.). Black boxes - position of Compensatory Base Changes (CBC) between $M$. frigidus and other species of the genus, forming one clade on the ITS2 tree with the newly described taxon.

Hanagata, N.; Malinsky-Rushansky, N. \& Dubinsky, Z. (1999): Eukaryotic picoplankton, Mychonastes homosphaera (Chlorophyceae, Chlorophyta), in Lake Kinneret, Israel. - Phycological Research 47: 263-269. DOI: $10.1046 /$ j.1440-1835.1999.00176.x.

HINDÁK, F. (1978): New taxa and reclassifications in the Chlorococcales (Chlorophyceae). - Preslia, Praha 50: 97-109.

Hindák, F. (1984): Studies on the chlorococcal algae (Chlorophyceae). III. - Biologické Práce 30/1: 1-308.

HiNDÁK, F. (1988a): Studies on the chlorococcal algae (Chlorophyceae). IV. - Biologické Práce 34(1/2): 1-264.
HiNDÁK, F. (1988b): Einige kokkale Grünalgen aus den Kärtner Seen, Österreich. - Archiv für Hydrobiologie 79: 446-501.

Kalina, T. \& Puncŏchárŏvá, M. (1987): Taxonomy of the subfamily Scotiellocystoideae Fott 1976 (Chlorellaceae, Chlorophyceae). - Archiv für Hydrobiologie 73: 473-521.

Keller, A.; Schleicher, T.; Schultz, J.; Müller, T.; DANDEKAR, T. \& Wolf, M. (2009): 5.8S-28S rRNA interaction and HMM-based ITS2 annotation. - Gene 430: 50-57. DOI: 10.1016/j.gene.2008.10.012.

KolesniK, S.V. (1964): Atlas of the Komi Republic. - 112 pp., Main Department of Geodesy and Cartography of the 
State Geological Committee of the USSR, Moscow.

KoMÁreK, J. \& FotT, B. (1983): Chlorophyceae (Grünalgen) Ordnung: Chlorococcales. - In: Huber-Pestalozzi, G. (ed.): Das Phytoplankton des Süßwassers, 7. Teil, 1. - 1044 pp., Hälfte, Schweizerbart'sche Verlagsbuchhandlung (Nägele u. Obermiller), Stuttgart

Krienitz, L.; Bock, C.; Dadheech, P.K. \& PröSchold, T. (2011): Taxonomic reassessment of the genus Mychonastes (Chlorophyceae, Chlorophyta) including the description of eight new species. - Phycologia 50: 89-106. DOI: 10.2216/10-15.1.

KrIENITZ, L.; Huss, V.A.R. \& HüMmER, C. (1996): Picoplanktonic Choricystis species (Chlorococcales, Chlorophyta) and problems surrounding the morphologically similar "Nannochloris-like algae". - Phycologia 35: 332-341. DOI: $10.2216 / 10031-8884-35-4-332.1$.

KrienitZ, L.; TAKEDA, H. \& HePPerle, D. (1999): Ultrastructure, cell wall composition, and phylogenetic position of Pseudodictyosphaerium jurisii (Chlorococcales, Chlorophyta) including a comparison with other picoplanktonic green algae. - Phycologia 38: 100-107. DOI: 10.2216/10031-8884-38-2-100.1.

Kumar, S.; Stecher, G.; Li, M.; Knyaz, C. \& Tamura, K. (2018): MEGA X: Molecular Evolutionary Genetics Analysis across computing platforms. - Molecular Biology and Evolution 35: 1547-1549. DOI: 10.1093/ molbev/msy096.

Margulis, B.L.; Hinkle, G.; McKhann, H. \& Moynihan, B. (1988): Mychonastes desiccatus Brown sp. Nova (Chlorococcales, Chlorophyta) - an intertidal alga forming achlorophyllous desiccation-resistant cysts. - Archiv für Hydrobiologie 78: 425-446.

McFadden, G.I. \& Melkonian, M. (1986): Use of Hepes buffer for microalgal culture media and fixation for electron microscopy. - Phycologia 25: 551-557. DOI: 10.2216/i0031-8884-25-4-551.1.

Medlin, L.; Elwood, H.J.; Stickel, S. \& Sogin, M.L. (1988): The characterization of enzymatically amplified eukaryotic 16S-like rRNA-coding regions. - Gene 71: 491-499. DOI: 10.1016/0378-1119(88)90066-2.

Müller, T.; PhilipPi, N.; DandeKar, T.; Schultz, J. \& WOLF, M. (2007): Distinguishing species. - RNA 13: 1469-1472. DOI: 10.1261/rna.617107.

PATOvA, E.N. (2010): Biodiversity of aquatic and terrestrial ecosystems of the Kozhym River Basin (Northern part of the «Yugyd va» national park). - 192 pp., Syktyvkar.

Patova, E.N. \& Novakovskaya, I.V. (2018): Soil algae of the Northeastern European Russia. - Novosti sistematiki nizshikh rastenii 52: 311-353. DOI: 10.31111/ nsnr/2018.52.2.311.

PosadA, D. (2006): Modeltest Server: a web-based tool for the statistical selection of models of nucleotide substitution online. - Nucleic Acids Res. 34: 700-703. DOI: 10.1093/nar/gk1042.

Pruesse, E., Peplies, J. \& Glöckner, F.O. (2012): SINA: accurate high-throughput multiple sequence alignment of ribosomal RNA genes. - Bioinformatics 28 : 1823-1829. DOI: 10.1093/bioinformatics/bts252.

Ramos, G.J.P.; Bicudo, C.E. de M. \& Moura, C.W. do N. (2015): Trebouxiophyceae (Chlorophyta) from Marimbus Wetlands, Chapada Diamantina, Bahia, Brazil. - Iheringia Série Botanica 70: 57-72.

Ronquist, F. \& HuelsenbeCK, J.P. (2003): MrBayes 3: Bayesian phylogenetic inference under mixed models. - Bioinformatics 19: 1572-1574. DOI: 10.1093/ bioinformatics/btg 180 .

Schultz, J.; Maisel, S.; Gerlach, D.; Müller, T. \& Wolf, M. (2005): A common core of secondary structure of the internal transcribed spacer 2 (ITS2) throughout the Eukaryota. - RNA 11: 361-364. DOI: 10.1261/ rna. 7204505 .

Seibel, P.N.; Müller, T.; Dandekar, T.; Schultz, J. \& WOLF, M. (2006): 4SALE - a tool for synchronous RNA sequence and secondary structure alignment and editing. - BMC bioinformatics 7: 498. DOI: 10.1186/1471-2105-7-498.

Simpson, P.D. \& Van ValKenBuRG, S.D. (1978): The ultrastructure of Mychonastes ruminatus gen. et sp. nov., a new member of the Chlorophyceae isolated from brackish water. - British Phycology Journal 13: 117-30. DOI: 10.1080/00071617800650131.

Thompson, J.D.; Higgins, D.G. \& Gibson, T.J. (1994): CLUSTALW: Improving the sensitivity of progressive multiple sequence through weighing, position-specific gap penalties and weight matrix choice. - Nucleic Acids Research 22: 4673-4680. DOI: 10.1093/nar/22.22.4673.

Treshnikov, A.F. (1985): Atlas of the Arctic. - 204 pp., Main Department of Geodesy and Cartography under the Council of Ministers of the USSR, Moscow.

Tsarenko, P.M. (2011): Chlorococcales. - In: Tsarenko, P.M.; WASSER, S.P. \& NEVO, E. (eds): Algae of Ukraine: diversity, nomenclature, taxonomy, ecology and geography, Volume 3, Chlorophyta. - pp. 232-264, A.R.A. Gantner Verlag K.-G, Ruggell.

White, T.J.; Bruns, T.D.; LeE, S.B. \& TAYlor, J.W. (1990): Amplification and Direct Sequencing of Fungal Ribosomal RNA Genes for Phylogenetics. - In: INNIS, M.A.; Gelfand, D.H.; Sninsky, J.J. \& White, T.J. (eds): PCR Protocols: A Guide to Methods and Applications. - pp. 315-322, Academic Press, New York. http:// dx.doi.org/10.1016/B978-0-12-372180-8.50042-1.

Wolf, M.; Chen, S.; Song, J.; ANKenBrand, M. \& MüLler, T. (2013): Compensatory Base Changes in ITS2 Secondary Structures Correlate with the Biological Species Concept Despite Intragenomic Variability in ITS2 Sequences - A Proof of Concept. - PLoS ONE 8: e66726. DOI: 10.1371/journal.pone.0066726.

ZUKER, M. (2003): Mfold web server for nucleic acid folding and hybridization prediction. - Nucleic Acids Research 31: 3406-3415. DOI: 10.1093/nar/gkg595.

Supplementary material

The following supplementary material is available for this article:

Table S1. List of known species of the genus Mychonastes with synonyms, morphological features and habitat preferences.

This material is available as part of the online article (http:// fottea.czechphycology.cz/contents)

(C) Czech Phycological Society (2021)

Received April 2, 2020

Accepted September 2, 2020 